\title{
Recruitment and Retention in Front-line Services: the case of childcare
}

\author{
Marilyn Carroll European Work and Employment Research Centre (EWERC), \\ Manchester Business School, University of Manchester
}

Mark Smith Grenoble Ecole de Management

Gwen Oliver, European Work and Employment Research Centre (EWERC), Manchester Business School, University of Manchester

Sirin Sung, School of Sociology, Social Policy and Social Work, Queen's University, Belfast

May (2006)

\begin{abstract}
In this paper we highlight how problems of recruitment and retention in front-line services create a particular challenge to traditional HRM models and solutions. The price-sensitive nature of front-line service work means that the scope for improving terms and conditions, that may ameliorate recruitment and retention difficulties, is often limited. The case of day nurseries make an interesting example of the challenges facing managers in the services sector as the combination of a feminised workforce, a price-sensitive service, public-private competition and state regulation all combine to create particular difficulties. We report on a study of 33 day nurseries which included interviews with both managers and employees over an eight-month period. Our findings show that childcare providers, particularly those in the private sector, are grappling with recruitment and retention problems associated with high-end interactive service provision that are compounded by gender segregation and small businesses characteristics. Our analysis of employer and employee perspectives highlight the importance of employee disillusionment/unsuitability, low pay, poor career prospects and difficulties of balancing work and family life. The growth in demand for childcare services means that these problems are unlikely to disappear.
\end{abstract}




\section{Introduction}

In many ways the front-line services present a particular problem to HR managers and traditional solutions to problems such as recruitment and retention. The price sensitive nature of front-line services means that the scope for improving terms and conditions that may ameliorate recruitment and retention difficulties is limited. Furthermore constraints on productivity growth limit the potential to raise value added and thus wages (Baumol 1967). The gender-segregated nature of many front-line services may compound problems by restricting the pool of available labour while reinforcing the low status. In the case of childcare the problems associated with front-line services are compounded by a number of sector specific characteristics. In addition to the gendersegregated labour supply and low pay, the emotional labour content of the job is particularly high; a source of both job satisfaction and stress neither of which are present in comparably paid jobs, for example in retail. Furthermore the highly regulated nature of the sector - requirements for a qualified workforce and ratios of staff to children - adds to the cost pressures that managers face, and traditional methods of dealing with excess demand or short-term staff shortages, for example queuing, are not necessarily possible.

Furthermore the sector-specific characteristics are compounded by the growth of the sector in recent years. The expansion reflects an increase in demand from working parents as well as the Government's National Childcare Strategy which includes Sure Start and childcare vouchers. Thus the issues of staff recruitment and retention are important at a number of levels. At the organisational level the sector demonstrates the challenges traditional HR approaches face in front line services. Although many managers recognise that it makes good business sense to reduce turnover rates they are constrained when compared to competitor employers, such as retail. However, for parents continuity of care is an important factor in using the service and dissatisfaction with the quality of care can threaten the organisation in another way. At the sectoral level, a high turnover of staff out of the sector results in skills shortages which not only need to be addressed but may also represent a wasted investment in skills and training given the qualification requirements of the sector.

Using evidence from case studies of 33 childcare providers in the North West of England, this paper examines recruitment and retention in the nursery sector. Although the focus of the paper is on retention, we also highlight recruitment difficulties as the two are inextricably linked. The paper is divided into five sections. The next section highlights existing research on recruitment and retention in the sector. The third section describes our research project and the fourth presents our findings. Here we examine the reasons for staff turnover from the perspectives of both managers and employees, and describe the strategies used by the managers in our sample to try to combat turnover. The fifth and final section concludes by highlighting the interaction of pay and status, career aspirations, family responsibilities, and work patterns on staff turnover. We also consider wider labour market issues, and the implications for the sector.

\section{Recruitment and Retention in the Childcare Sector}

Although the childcare sector is expanding, it faces a diminishing pool of labour from which to recruit (Rolfe et al., 2003, Simon et al., 2003). The reasons for this are, firstly, since the childcare workforce is still predominantly female (approximately 99 percent despite Government commitment to increase the numbers of men in the 
sector), almost 50 percent of the population is automatically excluded. Low pay and low status contribute to this gender segregated workforce (Owen, 2003; Edwards et al., 2003; Prentis, 2004). Furthermore, caring for other people's children has traditionally been seen as 'women's work' (Simpson, 2004; Sung et al. 2005). Secondly childcare workers have tended to leave school with lower than average qualifications and have been steered into childcare as one of the few career options open to them. However, as qualification levels of female school leavers rise, competition from the service sector for this pool of low qualified entrants has increased (Simon et al. 2003). Cameron and Moss (2002) also argue that the low rates of pay for childcare work mean that nurseries compete with other sectors, such as retail, which offer less demanding jobs for similar or higher pay. Thirdly, women's increasing academic achievements mean that they have higher career expectations and, the sector now also faces competition from other, higher paying and higher status sectors, such as healthcare and education (Simon et al., 2003). Fourthly poor pay also has an influence on how the work is valued and, as Owen (2003) points out, childcare work is low paid, even when compared with other traditional female jobs. Fifthly, some studies also point to the fact that childcare work does not combine easily with caring for one's own children (Cameron et al, 2003; Smith et al., 2004), and this also influences recruitment and retention. The age distribution of nursery nurses peaks twice - at under 25s and 35 to 49 year olds (Simon et al., 2003) suggesting that women in the main childrearing years are unable, or unwilling to pursue a career in childcare while parenting young children.

Service work typically includes a degree of inseparability of the customer from the service (Mills, 1986; Leidner, 1993) and front-line service work emphasises this with a three-way relationship between employer, employee and customer. In this type of service work it is the role of the customer that is 'the most important unique aspect' (Korczynski, 2002;2). If the child is regarded as the customer, nursery nursing, like teaching and healthcare work, can be seen as high-end interactive service work, where the interaction with the customer is, in effect, the product being sold (rather than, say, a burger or insurance policy). In fact, the relationship can be seen as a four-way one, as childcare workers also interact with the buyers of the service as they balance the demands of employer, children and parents.

Childcare work has a high emotional labour content. The concept of emotional labour has been associated with front-line service sector work, especially in those jobs typically performed by women, in which the worker's behaviour, demeanour and appearance when interacting with the customer are seen as crucial to service delivery. As the term implies, emotional labour has always been a feature of the caring professions, a fact which Korczynsky (2002) points out, had largely been ignored by academics until the publication of Hochschild's book, The Managed Heart (1983), which was concerned with emotional labour of flight attendants and debt collectors. While the effects of emotional labour have been identified as a contributory factor to stress and burn-out among call centre workers (Taylor and Bain 1999), emotional involvement with the customer can also be seen as a source of pleasure for many workers (Tolich, 1993), and that empathy with the customer may be a genuine, rather than a forced reaction (Bolton and Boyd, 2003). Furthermore, where interactions are socially embedded (Granovetter, 1985) and workers are allowed a greater degree of autonomy in how the work is carried out, the emotional aspect of work can be a source of job satisfaction (Wharton, 1993; Frenkel et al., 1998). The emotional labour 
required of childcare workers can be seen as a positive, instinctive, rather than destructive element of their work, since smiling at, and behaving empathetically towards, small children is something that many adults naturally do. This is borne out by research in the childcare sector which reports high levels of job satisfaction among childcare workers (Cameron et al., 2001; Rolfe et al., 2003). For many childcare workers, therefore, the intrinsic rewards they receive from the work outweigh the disadvantages which we describe below, and have a positive effect on retention as they choose to remain in childcare. For others, however, the emotional labour involved in the work, even if they do not see it in those terms, may be a deterrent from entering the childcare workforce, or may be a source of stress and frustration, leading to retention problems of those who do not see childcare work as their natural vocation.

Gender segregation of employment is linked to the high emotional labour content and plays a key part in the management of service-sector workers. Women's disadvantage is reflected their concentration in certain types of low-paid work, especially front-line service work. This could be a result of women's relatively weak labour market position, or the social construction of male and female work or, as Scott (1994) argues, a combination of the two. Korczynski's (2002) 'Customer-orientated bureaucracy' suggests that managers adopt cost minimisation strategies and responding to perceived customer preferences leading to concentrations of women in front-line occupations. We argue that the childcare sector provides a clear example of this type of relationship. Nursery managers hire women who are more likely to accept the low-pay rates associated with childcare work but who also reflect the personal preferences of higher status parents (Sung et al 2005). Although this is maybe a 'rational bias' it is, nevertheless, discriminatory (Trentham and Larwood, 1998).

It has been suggested that service-sector jobs require specific types of HRM interventions which differ from those relevant in manufacturing, in order to gain competitive advantage (Korczynski, 2002). The 'new service management school', proposes a normative, prescriptive model for HRM in service work and suggests good quality HR practices (selection, training, support systems, empowerment, teamwork, performance measurement, rewards and recognition) will assure staff commitment and in turn, will have positive effects on service and customer satisfaction (for example Heskett et al, 1997, Schneider and Bowen, 1995, Zeithamel and Bitner, 1996). This model has been criticised on the grounds that it is essentially unitarist in nature and leaves no room for the possibility of conflict in the employer/employee relationship. Furthermore the emphasis on best practice ignores contingent theories of HRM. Neither is it supported by empirical evidence which suggests that much service sector work is characterised by low pay, lack of empowerment/discretion, low unionisation, minimal training, few career prospects and invasive methods of performance measurement and surveillance leading to high levels of staff turnover (Towers, 1997; Metcalfe, 1999; Taylor and Bain, 1999).

One aspect of the childcare sector which makes it particularly useful for the study of front-line service work is the prevalence of small firms. While much of the literature on HRM in service work concentrates on large employers in areas such as banking, call centres, airlines, retail and hospitality, 85 percent of childcare providers are owner-managed, single site small businesses (Low Pay Commission, 2003). The debate about the nature of employment in small firms has tended, in the past, to be 
represented by polarised 'small is beautiful' or 'bleak house' scenarios (Wilkinson, 1999). Writers such as Rainnie (1989) challenge the view that employment in small firms is harmonious, characterised by co-operation and close working relationships, painting a picture of dictatorially run establishments with poor working conditions. Others (e.g. Ram, 1994; Holliday, 1995; Matlay, 1999) argue that these polarised views are over-simplified and that the small firm sector cannot be presented as homogeneous. In terms of recruitment and retention, however, research has shown that small businesses do tend to display certain distinctive characteristics which set them apart from large ones. Small firms are less likely to be able to sustain internal labour markets (Lane, 1994; Hendry et al., 1995) and, as a consequence, may not be able to retain key staff. Carroll et al. (1999:248) report 'an almost fatalistic acceptance of high turnover rates' by small firm managers. Lack of career opportunities in small firms has implications for recruitment, since they are unlikely to be able to compete with large firms for high calibre staff (Ritchie, 1993; Atkinson and Storey, 1994; Thatcher, 1996) and, as a result, they tend to complain about the quality of labour available to them (Scott et al., 1989). Indeed, Atkinson and Storey (1994) note that small firms report labour market problems more frequently than any other, and argue that it is only when firms cease to be small that these problems can be resolved. Furthermore poor individual recruitment decisions are likely to have more serious consequences for these businesses precisely because they are small in size and, consequently, they are more likely to use informal, word-of-mouth recruitment methods. Hiring a known quantity poses fewer risks as the new recruit is more likely to be able to fit in with their colleagues and the existing culture of the firm (Scott et al., 1989, Atkinson and Meager, 1994., Holliday, 1995; Carroll et al., 1999; Marchington et al., 2003). However, as Carroll et al., (1999) point out, these methods can reinforce existing gender and race imbalances within the workforce, leaving a pool of potentially suitable recruits untapped.

Some studies point to the precarious financial nature of many small businesses leading to job insecurity (for example Atkinson and Storey, 1994). Day nurseries are highly labour intensive with labour costs, in common with other service sector industries, usually amounting to around 60\% (NDNA, 2004). The fact that they are highly regulated means that they are unable to reduce staff numbers without reducing nursery places (Low Pay Commission, 2003). Increasing fees to pay for wage increases could make the already high costs of nursery places unaffordable to many parents, and call into question the long-term viability of the business (Smith et al. 2004). Thus childcare workers not only face the conditions of employment in frontline service work which is highly segregated by gender, low paid and demanding, but many of them are also disadvantaged by the conditions of work in small firms, where informal management practices and financial constraints mean that typical HRM remedies simply do not exist.

\section{The Research}

The project was funded by the European Social Fund and involved research in 33 nurseries across the North West of England. Formal childcare providers were selected from seven areas to reflect a mixture of urban and more rural as well as more and less affluent, in each area at least four establishments were researched. Within these geographical areas we also selected a mix of public and private providers of childcare. Interviews were undertaken with employees and management, in total more than 130 over an eight-month period. Management interviews focused on the policy and 
practices of individual organisations as well as the characteristics of local labour markets that influence the recruitment and retention of employees. These were supplemented by interviews with further contacts at the local authority level to enhance the local area data. In the third stage, interviews with employees in the target organisations were carried out. These focused on the motivations, constraints and career trajectories of employees working in the sector. In addition to the interviews, organisational and employee characteristic data were collected.

\section{Managers' and Employees' Perspectives on Recruitment and Retention}

Three fifths of managers in our sample (20), said they had experienced difficulties attracting staff and just less than half (14) identified staff recruitment as a major problem impacting on the running of the business. Some managers had no problems recruiting nursery assistants, but had difficulty finding qualified and experienced staff for supervisory and deputy management positions. Often recruitment advertisements attracted a good response, but managers complained about the quality of the applicants, including the standards of students from childcare courses. Thirteen said they had not experienced recruitment problems but of these, two were very small settings in isolated rural areas which had not had any recent recruitment needs. Others were nurseries attached to FE colleges, where the recruitment function was carried out by a separate personnel department, where pay and conditions tended to be better, and which had the advantage of having a ready-made pool of potential recruits from their own childcare courses.

Despite reporting problems with recruitment of staff, and despite high staff turnover rates widely reported elsewhere as endemic in the sector (Rolfe et al., 2003), none of the managers or owners we spoke to said that staff turnover was a problem in their particular nursery. In fact, they all said that staff turnover was low, or even nonexistent. A typical response was 'we've only had two people leave in the last year' (although taken in a context of a small setting, this could amount to a turnover rate of $25 \%$ ). When staff did leave, managers tended to highlight one of four reasons: unsuitability, financial reasons, career reasons or family reasons. Employee perspectives of retention issues were instead explored by asking current employees about their future plans for work, motivations for working in childcare, what they liked and disliked about the job, and whether or not they thought working in the childcare sector was compatible with caring for children of their own. Just over a third of the employees (30) we interviewed said that they had no plans to change their jobs within the next five years. However, more than half of employees (44) were anticipating either a move to another nursery or moving out of day nurseries altogether. Analysis of employees' responses allows us to identify four broad explanations for employees who wish to leave. Three of these categories correspond closely with the explanations given by managers - own care responsibilities, career progression/promotion and pay - while the fourth, labelled 'disillusionment with the work', could be said to correspond most closely with the 'unsuitability for the work' category identified by managers. We consider each of these factors in turn.

\section{Unsuitability/Disillusionment}

According to the managers, staff turnover was highest amongst trainees and younger workers who found that the reality of working in a nursery setting was not what they imagined it to be. According to one manager of a nursery in Manchester 'you always get that!' Another explained: 
People of seventeen or eighteen don't know what to expect. They think that children are happy and smiling all the time, and children just aren't (Officer-in-Charge, Manchester).

Sometimes managers found that these young recruits lacked the necessary qualities to work in childcare. Managers stressed the need for the right personality, the right characteristics, and the ability to fit in. Strategies to reduce turnover in the earlycareer stages included offering recruits a pre-employment 'fly-on-the-wall' experience, and careful selection techniques, including observing how applicants relate to the children.

One nursery had changed its recruitment procedures and now selects its own trainees, rather than relying on a training organization to supply them:

[Turnover has] not been a problem when we have selected them ourselves. I think it's a problem if - in the past when [the training organization] used to send people and you'd be thinking, 'hang on a minute - what is this person doing in childcare?'(Nursery Principal, Cheshire).

Some managers admitted that they had made some poor recruitment decisions, but typically new starters were taken on a three-month probation period before being given an open-ended contract, and those who were unsuitable could leave, or be asked to leave, within this period:

It doesn't happen very often, but it has just happened twice. I knew in a very short while that they were not the kind of person I thought they were (Nursery Owner, Manchester).

Rather than seeing themselves as unsuitable for childcare work, employees tended to focus on other aspects of the job with which they were disenchanted, for example the conditions and the low status. Employees were asked why they chose to work in childcare, and there was evidence of ambivalence among many of those who expected to leave. One employee remembered that it was 'what I wanted to do at the time of leaving school. That was it really'. Others suggested that they might have made a different decision; one employee explained that the only career choices suggested to her were hairdressing or childcare, while another thought she might not have chosen childcare if she had done better at school:

Basically I needed to decide to do something, and I chose this. Looking back now I would probably have done things a lot differently. I would probably have tried harder at school and got better qualifications and actually seriously thought about what I wanted to do. It was getting to that time where I needed to pick something. I quite like children so that is what I went for. (Nursery Officer, Lancashire, 28 yrs old)

This employee later admitted to finding the job 'a bit boring and very much the same every day', and was hoping to work somewhere else, 'taking some promotion, a better job I think'. Similarly, another nursery officer said that she had originally wanted to do teaching but 
I left school and went to sixth form but then I didn't like sixth form so that is when I came here. (Nursery Officer, Cumbria, 24 years old).

Other employees claimed they always wanted to work in childcare but were still disillusioned with the job. One nursery officer explained that she chose childcare as a career because it was "...just something I have always wanted to do [and] what I wanted to do at the time of leaving school". However, this respondent no longer wanted to work in a nursery because as well as being badly paid, she felt that 'you don't feel appreciated'. Disillusionment had already caused her to give up on an NVQ course that required her to be at college for one day a week, reasoning that there was no point 'as the money was not going to go up and I was losing a day's pay'.

Once past the early stages of employment the managers in our sample said that when staff did leave, managers felt it was usually for a 'good' reason - pay, career or family - and not because they were unhappy with the job or the nursery. There was a perception amongst managers that leaving for these reasons was not only acceptable, even desirable, but an inevitability that they could do little about; something that 'goes with the territory'.

\section{Low Pay and Low Status}

According to managers, the most important reason for staff turnover in the sector as a whole was low pay, or low pay and low status in relation to the high levels of responsibility. Comparisons were often made with the retail sector:

Because of the pay scale that nursery nurses get, and the intensity of the courses and the work these girls have to put in for the money that they receive, they could get the same working in Top Shop or Asda without the responsibility (Owner/manager, Lancashire).

You're in charge, if you are on the under-twos, for three lives, and people on the checkouts are getting more. It's so sad (Nursery Principal, Cheshire).

Employees also frequently pointed out that the retail sector in particular offered higher wages for less responsibility. However, it was not evident that employees would be tempted enough to actually move, rather, examples of higher wages tended to be used to illustrate the unfairness in their wages. For example;

No, no. No way, because I have looked at other professions like supermarkets, seven to eight pounds per hour and I'm sorry, but we do a lot more work. The perception from the outside is that all we do is play with children (Nursery Assistant, Manchester, Male, early 20s).

I used to work behind a till and got paid better at Iceland for doing less (Nursery Nurse, Cheshire, 19 years old).

Other employees compared their situation with that in the rest of the education system: 
That salary [£5.70] was offered to me as the deputy manager's role so no, I didn't think that was the right salary for the deputy manager. ... But no, comparing it with school - I am a teaching assistant in the school - I know it is paid by the government, and this is private but there has got to be somewhere in between. (Room Supervisor, Cumbria, 29 yrs old).

Not only did childcare workers' pay compare unfavourably with other sectors, but the private day nurseries in our sample competed for childcare workers with the public sector, where pay and conditions were better. This was a particular problem for the inner cities and less affluent areas, where local authority nurseries paid around thirteen to fourteen thousand pounds a year, whereas even qualified staff in the private sector were often on the minimum wage:

..obviously we're not as high as in the LEA or the Sure Start local programmes. You can't compete with those. (Nursery Manager, Lancashire).

I am very well aware of where all of our staff have gone. There is not one member of staff that has gone to another private nursery (Nursery Manager, Lancashire).

Low pay also means that childcare workers are very rarely either financially independent, or the main breadwinner in a household, so another common reason for leaving, according to the managers, was relocation necessitated by a career move by another member of the family. This could include not only the spouse or partner of the childcare worker, but also, in the case of younger workers living at home, a parent. The majority of the employees we interviewed lived with a partner or with their parents, and so pay, while acknowledged as being low, was not an immediate concern for them as they were not the sole or main breadwinner in their household. However, employees recognised that in the future income would not suffice:

In the private sector, managers found it difficult to increase salaries substantially without putting up the nursery fees to an unaffordable level. However, of the private sector nurseries, four managers said they paid above 'the competition' as a way of attracting and retaining staff. At the lower end, recent annual increases had been necessitated by increases in the National Minimum Wage, and more senior staff were often given a pro-rata increase at the same time, to maintain differentials. Some of the larger nurseries, and those attached to further education colleges, had formal pay scales, and three of the other smaller ones tried to give regular or more frequent pay rises, based on age, experience, length of service, qualifications and responsibilities. Just three of the nurseries had a staff bonus system awarded either on occupancy of the nursery, personal development, or to staff who showed 'particular initiative'. Another three nurseries gave non-pay 'perks' including free Christmas dinners, presents, prizes for quizzes and 'employee of the month' awards.

\section{Career Prospects}

In many cases, managers admitted that opportunities for promotion in their particular setting were limited; a problem faced by small businesses in general. Conversely, promotion opportunities could be an outcome of high staff turnover. However, in a 
small setting with a stable workforce, ambitious and experienced staff find it necessary to leave if they wanted promotion, and managers said that they would not wish to stand in the way of someone who wanted to further their career by moving to another nursery. However, many childcare workers left for other career-associated reasons; to go into full-time education, to train for a different, or 'better', more highly-paid, or higher status career, typically nursing, teaching or social work. Again, managers did not discourage this, and some positively welcomed it:

That's the problem you know. You provide additional training and then they say, 'Bye!', which is good. I am not in any way complaining (Owner/Manager, Cumbria).

Again, managers felt that there was nothing they could do to stop this haemorrhaging of the childcare workforce into other professions; only a national initiative to raise the pay and status of childcare workers would prevent this.

Career progression was often cited by employees as a reason for leaving. Eleven employees who wanted promotion said that they would be willing to go to a different nursery in order to move up a level. Those working in smaller private nurseries were more likely to expect to find it very difficult, if not impossible, to progress in their current nursery, and would consider moving even if they would rather stay:

Yes, I would have to [commute] and there would be childcare problems so I just kind of keep putting it off. But I think I will have to because financially and also, sort of, professionally I would like to move my career on because I don't feel it is going anywhere here. (Principal Teacher, Cumbria, 32 years old, 2 children).

Career progression was also mentioned by those planning on leaving the sector altogether, often in the context of their personal development and fulfilment. For example, a team leader expressed a wish to have 'a career for herself' and hoped to apply for midwifery. Those with higher qualifications were more likely to mention personal fulfilment. One nursery nurse with a degree in psychology explained that she had always wanted to work with children at 'grass roots' level, but that she would much prefer to be working as a teacher of key stage one, stating that 'I don't want to waste my intelligence, if you know what I mean'. Other career ambitions included play therapist, the police or, most commonly, a teaching assistant in a primary school. Work as a teaching assistant was attractive to employees because of the better pay and conditions, but some employees also mentioned that the job was seen as more rewarding and having higher status than being a nursery nurse:

I do feel a bit like, dogsbody type at the moment, whereas in the school set up I am a teaching assistant in the school working alongside the teacher. And I absolutely love it there because the children see us both as in the same role (Room Supervisor, Cumbria, 29 yrs old).

Interestingly three of the male employees that were interviewed were planning on becoming either a primary school teacher or a teaching assistant in a primary school. 


\section{Work-life balance}

The final category of reasons for leaving, family reasons, included leaving to have a baby, leaving because existing childcare arrangements had broken down, or leaving to work in another job, either within or outside the childcare sector, with shorter hours, or school hours, in order to combine work and family responsibilities. The most common strategies used by employers to combat turnover associated with family reasons was to offer reduced fees at the nursery (20 nurseries in the sample), or some flexibility of working hours (15 nurseries in the sample). Managers had lost staff who had gone into childminding because they couldn't afford the nursery fees.

Offering working-time flexibility could be a problem because of the necessity to adhere to the ratios and to provide adequate cover, particularly at the beginning and end of the day. According to one manager,

I have said, if we can accommodate that, that's fine. But I can't be put in the position where I've got four staff with children who want to do eight till three. (Owner/Manager, Lancashire).

At another nursery, which did offer part-time working and job share, the manager stressed that this had to fit round the needs of the business, rather than the personal needs of the employees. However, other managers went out of their way to accommodate the working time preferences of their staff, or to reach a compromise acceptable to both parties:

Oh, there's huge flexibility, let me tell you! You just have to look at my diary! I am probably too flexible, but I try my best to help people (Nursery Head, Manchester).

On the other hand, one nursery, which offered neither childcare for employees (because the manager believed 'it doesn't really work'), nor any flexibility in working time, had recently lost members of staff because of the working hours. Interestingly, at the time of the interview, none of the staff at this nursery had young children.

The interviews with employees also confirmed that childcare was one of the most common reasons for staff turnover. Around a third of employees who wanted to leave cited their own current childcare responsibilities or their desire to have children when talking about future plans. Two employees spoke of plans to become childminders as this would allow them to work and care for their own children at the same time, while others were planning to work in a school because of the shorter hours and term-time working arrangements. Only one employee said that she would give up work altogether if she had children.

Reasons given for not wanting to combine parenting and childcare work or not wanting to continue to do so were both financial and time based. Some hoped that childminding would solve the problem:

I am going to just start childminding...then I can be with him, but he would also go to a state nursery. That gives him his independence in the mornings or in the afternoons but I still get to see him more than I would 
do if he was in [another room in this nursery] (Senior Nursery Nurse, Cheshire, 20 years old).

while another predicted that she would have to work part time because of the costs of childcare:

I'd hope to [carry on working], but it's very expensive to get children in nurseries anyway, especially full time, so I don't think I'd be able to afford full time, but if I was working part time and could get a couple of days at the nursery, maybe that would be all right (Nursery Nurse, Lancashire, 19 years old)

However, among those without children, the idea of combining childcare with parenting was an undesirable one, even if it was considered practically possible. Some were clearly aware of the contradiction of being paid to look after other people's children knowing that someone else was looking after theirs, or paying someone else to look after theirs:

If I had to work, I wouldn't work with children because I wouldn't want to work with other people's children knowing that my child would have to be looked after by someone else. (Senior Nursery Nurse, Cheshire, 22years old).

I don't know if it would be worth me going back to work. I would be paying people to look after my child, and that's where all my money goes, so what would the point be to that? (Nursery Nurse, Lancashire, 25 years old).

In other cases employees believed that working with children all day and coming home to look after their own children was equally undesirable, as it would be 'too much' to deal with, although this did not necessarily mean that they did not want to work at all:

..all day you are just with kids and then when you come home you will want to have special time with your children. And I don't know, you would be thinking 'oh I have been doing this all day!' (Nursery Nurse, Manchester, 20 yrs old).

I think I would like to do part time, not full time and then go home and start again! (Nursery Officer, Manchester, 20 years old).

Employees were more inclined to be positive about combining parenting and working in childcare if their colleagues were managing to do it. One nursery nurse believed it was possible to combine the two after watching colleagues with children manage to continue working. Similarly employees without children who did want to stay with their current employer, generally had much more positive attitudes towards combining childcare work with children of their own (14 out of the 21 respondents in this category).

\section{Summary and Conclusions}


Our findings show that childcare providers, particularly those in the private sector, are grappling with recruitment and retention problems associated with high-end interactive service provision that are compounded by gender segregation and small businesses characteristics. Our analysis of employer and employee perspectives highlight the importance of disillusionment/unsuitability, low pay, career prospects and difficulties of balancing work and family life.

Our research has reinforced previous studies which point out that the pool of recruits to the childcare workforce is largely restricted to a particular group, mainly young women, who have 'always wanted to work with children' and who chose the job for its intrinsic rewards rather than pay or status, or those whose educational achievements prevent them pursuing higher status careers. Childcare work was clearly a very enjoyable occupation for many of the nursery nurses we interviewed, supporting the notion that the emotional labour required of them was indeed a source of job satisfaction (Tolich, 1993). However, the traditional pool of recruits is decreasing as women's educational achievements and career aspirations improve and once employers recruit from beyond this 'dedicated' group recruitment and retention problems tend to increase. The problem of disillusioned/unsuitable employees can be seen as evidence of this. It is these employees who are perhaps the most likely to be attracted away from the sector to other types of work that offer better pay. As demand for childcare rises and the aspirations of women leaving school increases employers are faced with a dual challenge. Recruiting among those with other opportunities is hard when pay and conditions are so low yet potential recruits with few alternatives who are ambivalent about childcare may be hard, or even undesirable, to retain.

The other explanations for recruitment and retention problems that we identify reflect the structure of the service as much as the labour supply. The impact of limited career progression, caring responsibilities and low pay have been dealt with separately here but are not independent of each other or the gender segregated nature of the labour force. In many cases a desire to leave the sector or the establishment was the result of an interaction of two or more of these factors. Low pay pervades the sector and decisions around joining or remaining in the sector. Employer and employee references to 'better-paid' retail work highlight both the low pay and the sense of unfairness in pay. Low pay also reinforces the position of women in the sector as secondary earners who are also more likely to sacrifice their own career for a higher earning partner's, for example by relocating, adjusting their employment decisions or leaving the labour market altogether.

While nursery managers can draw on the vocational aspect of childcare work and a growing demand for the service they provide, many difficulties stem from the size of establishments in the sector. Characteristically for employees of small business, the lack of opportunity for career progression in day nurseries was an important factor in decisions to leave, especially for employees who were more highly qualified than their counterparts. Employees could see that their only chance for promotion (and therefore a higher salary) was if someone in a higher position left, and so were resigned to the fact that they would have to move to another nursery if they wanted to progress.

Another challenge facing small businesses is how to cope with staff with caring commitments. In a nursery setting such problems are not only compounded by the 
almost exclusively female workforces but also by some employee's views that working in a nursery while others looked after their own children was problematic. The most common solution for accommodating employees with children was thought to be part time work, or flexible working hours. However, the opening hours of the nurseries, and, consequently the working hours of the staff, have to fit in with the needs of the parents who use the service and such constraints were restricting the flexibility that managers were able to offer their staff (Smith et al 2004).

It has been suggested that one way to overcome the recruitment problems which the sector faces as it continues to expand is to recruit from under-represented groups, such as men, older workers and ethnic minorities. Although local authorities have targets for these groups in their childcare workforce, only one of the nursery managers in our sample was actively trying to recruit them. There may be a perception that older people or men are not suited to childcare work or, in the case of men, peer pressure may prevent them entering the profession. However, many of the managers we spoke to said they would like to employ more men, but 'they just don't apply', often because of the low pay. The difficulties of attracting people who would not normally consider a career in childcare were independently highlighted by both managers and employees in our research. In response to recent recruitment efforts attracting people to work in childcare one respondent pointed out that "there's probably lots of people that do want to work in childcare, but they can't because of either pay, salaries, the norm, or how they fit it in with their family life".

These recruitment problems look set to continue as Government policies and demand from parents drives further expansion in the sector. This further expansion, including Sure Start initiatives and extended schools, may well exacerbate the problems currently faced by the private day nursery sector as it struggles to compete for recruits with the better-paying public sector. Furthermore, there have been moves to extend nursery opening hours - even to open 24 hours - as a result of new demands from parents for whom Government policies have made nursery care accessible, and whose working patterns may not conform to the working hours of parents who have traditionally used day nurseries. Extended hours may make recruitment even more difficult in a sector where many (mainly female) employees currently struggle to combine their working hours with their own childcare responsibilities. On the positive side, the expansion of the sector to provide a wider range of services, including the establishment of Children's Centres, could provide an opportunity for the sector to establish a wider and more diverse range of career opportunities, which may make it more attractive to a pool of potential recruits who are discouraged from pursuing a career in childcare because of the low pay and status of the profession. 


\section{Bibliography}

Atkinson, J. and Storey, D. (1994). 'Small Firms and Employment' in Employment, the Small Firm and the Labour Market. J. Atkinson and D. Storey, (eds.), London: Routledge.

Baumol, W. J. (1967). 'Macroeconomics of unbalanced growth: the anatomy of urban crisis'. American Economic Review, 57: 3, 415-26.

Bolton, S. C. and Boyd, C. (2003). 'Trolley Dolly or Skilled Emotion Manager? Moving on from Hochschilds's Managed Heart'. Work, Employment and Society, 17: 2, 289-308.

Bowen, D. and Lawler, E. (1995). 'Organising for Service: empowerment or production line?' in Understanding Service Management. W. Glynn, and J. Barnes (eds.), Chichester: John Wiley.

Cameron, C. and Moss, P. (2002). 'National Report UK: surveying demand, supply and use of care' in Care work in Europe: Current understandings and future directions. Thomas Coram Research Unit, Institute of Education, University of London.

Cameron, C., Moss, P. and Owen, C. (2001). Entry, Retention and Loss: A study of childcare students and workers. DfES Research Report 275.

Carroll, M., Marchington, M., Earnshaw, J., and Taylor, S. (1999). 'Recruitment in Small Firms: processes, methods and problems'. Employee Relations, 21: 3, 236-250.

Childcare Today, November 2006. London: Day Care Trust.

Evans, M. (2004). 'Pay Survey 2004'. Nursery World, September, 21-24.

Frenkel, S., Tam, M., Korkzynski, M. and Shire, K. (1998). 'Beyond bureaucracy? Work organisation in call centres'. International Journal of Human Resource Management, 9, 957-979.

Granovetter, M. (1985). 'Economic action and social structure: the problem of embeddedness'. American Journal of Sociology, 91, 481-510.

Hendry, C., Arthur, M. B., and Jones, A. M. (1995). Strategy through People Adaptation and Learning in the Small-Medium Enterprise, London: Routledge.

Heskett, J., Sasser, E. and Schlesinger, L. (1997). The Service Profit Chain, New York: Free Press.

Hochschild, A. (1983). The Managed Heart, Berkeley: University of California Press.

Korkzynski, M. (2002). Human Resource Management in Service Work, Basingstoke: Palgrave Macmillan.

Lane, D. A, (1994). People management in small and medium sized enterprises, Issues in People Management No. 8, London: Institute of Personnel and Development.

Leidner, R. (1993). Fast Food, Fast Talk, Berkeley: University of California Press.

Low Pay Commission (2003). The National Minimum Wage: Building on Success, Fourth Report of the Low Pay Commission, Norwich: TSO.

Metcalf, D. (1999). 'The Low Pay Commission and the National Minimum Wage'. Economic Journal, 109, 46-66.

Mills, P. (1986). Managing Service Industries, Cambridge MA: Ballinger

.National Audit Office (2004). Early Years: progress in developing high quality childcare and early education accessible to all, HC 268 Session 2003-2004, London: The Stationery Office.

OECD (2007) www.oecd.org/els/social/family/database (accessed 2/10/07) 
Owen, C. (2003). Men's Work? Changing the gender mix of the childcare and early years workforce, Thomas Coram Research Unit, University of London.

Ritchie, J. (1993). 'Strategies for Human Resource Management: challenges in smaller and entrepreneurial organisations' in Human Resource Management, Issues and Strategies. R. Harrison, (ed.), Wokingham: Addison-Wesley.

Rolfe, H., Metcalfe, H., Anderson, T. and Meadows, P. (2003). Recruitment and Retention of Childcare, Early Years and Play Workers: Research Study, Research Report No. 409, London: National Institute of Economic and Social Research.

Schneider, B. and Bowen, D. (1995). Winning the Service Game, Boston MA: Harvard Business School Press.

Scott, A. (1994). 'Gender segregation in the retail industry' in Gender Segregation and Social Change. A. Scott (ed.), Oxford University Press.

Scott, M., Roberts, I., Holroyd, D. and Sawbridge, D. (1989). Management and Industrial Relations in Small Firms, Department of Employment Research Paper No. 70.

Simon, A., Owen, C., Moss, P., Cameron, C. (2003). Mapping the care workforce: Supporting joined-up thinking: Secondary analysis of the Labour Force Survey for childcare and social care work, Thomas Coram Research Unit, Institute of Education, University of London.

Simpson, R. (2004). 'Masculinity at Work: the experiences of men in female dominated professions'. Work, Employment and Society, 18: 2, 349-368.

Smith, M., Sung, S., Carroll, M. and Oliver, G. (2004) 'Working in the Childcare Sector: the tension of providing and accessing care'. Paper presented at the Work, Employment and Society Conference, September.

Strober, M. H., Gerlach-Downie, S. and Yeager, K.E. (1995). 'Child care centers as workplaces'. Feminist Economics, 1: 1, 93-119.

Sung S., Smith, M., Carroll, M. and Oliver, G. (2005). 'Men in the Childcare Sector: Experience and Perspectives'. Paper presented at the Gender, Work and Organisation Conference, June.

Taylor, P. and Bain, P. (1999). 'An assembly line in the head: Work and employee relations in the call centre'. Industrial Relations Journal, 30:2. 101-117.

Thatcher, M. (1996). 'The big challenge facing small firms'. People Management, 25 July, 20-25.

Tolich, M. B. (1993). 'Alienating and liberating emotions at work'. Journal of Contemporary Ethnography, 22: 3, 361-381.

Torrington, D., Hall, L. and Taylor, S. (2005). Human Resource Management, Harlow: Pearson Education Limited.

Towers, B. (1997). The Representation Gap, London: Routledge.

Trentham, S. and Larwood, L. (1998). 'Gender Discrimination and the Workplace'. Sex Roles, 38: 1-28.

Wharton, A. (1993). 'The affective consequences of service work: managing emotions on the job'. Work and Occupations, 20: 2, 205-232.

Zeithaml, V. and Bitner, M. (1996). Services Marketing, New York, McGraw-Hill. 